\title{
Settler justice and Aboriginal homicide in late colonial Australia
}

\author{
Mark Finnane*
}

This article examines the hidden history of criminal justice in late colonial Australia by focussing on Aboriginal inter-se offending. Most Aboriginal defendants appearing in late colonial criminal courts were prosecuted for violent crimes against other Aboriginal people. The article explores how common such cases were and the degree to which the acknowledgment of cultural difference affected justice process and outcomes. The frequent invocation of 'custom' commonly led juries to recommend the mercy of the Crown to those Aboriginal defendants found guilty of committing a homicide. I argue that 'custom' was increasingly used by settler judicial processes as a shorthand way of explaining what was otherwise seen as unexplainable. In the twentieth century 'custom' would receive greater attention through the development of jurisprudence and policy around the idea of customary law.

* Mark Finnane is ARC Australian Professorial Fellow, ARC Centre of Excellence in Policing and Security, Griffith University. This article draws on research conducted for an ARC project on 'Responses to violence in Australian history' (DP 0771492). Thanks are due to John Myrtle and Jonathan Richards for research assistance and to the referees and editors for their comments and suggestions.

In Australian settler history and historiography encounters of Aboriginal people with the criminal justice system have been most noticed when they arose from inter-racial offences. The Governor brothers (who killed a settler family), Dhakiyarr (who killed a white policeman), Rupert Max Stuart (convicted for the rape and murder of a white girl) - these are the well known examples that attracted great attention in their time and later 
for what they signified about white Australian values and prejudices. ${ }^{1}$ Recent historical studies of colonial criminal law affecting Indigenous peoples have also generally focussed on inter-racial offences ${ }^{2}$ However significant such studies may be for understanding settler-Indigenous relations in their broader context, the reality is that most encounters of Indigenous people with the Australian criminal justice system were more commonly on account of offences committed against each other (inter se), as they continue to be. ${ }^{3}$ This was true of the frontier period as Broome has recently argued ${ }^{4}$ and also true of the decades after the frontier conflicts. Foundational cases like Murrell (NSW 1836), Wewar (Western Australia, 1842) and Larry (South Australia, 1847) resolved the question-mark hanging over colonial jurisdiction in such inter se offences. But such resolution was just the starting point of debates over how Aboriginal people would be brought into court, who would witness for or against them, how their guilt as to intention to commit a crime would be determined, and how they would be punished if found guilty. ${ }^{5}$

In this article I examine briefly the available evidence about the scale of inter se offending as it found its way through Australian courts historically. I then consider some selected cases that highlight the debates occurring within and outside court-rooms about the role of criminal trials and punishments in responding to inter se violence. Through those cases we see the degree to which Australian law in the courts came to hear Aboriginal witnesses, to interpret the context of Aboriginal offending, to adjudicate guilt and to mitigate punishment. In parliament, bureaucratic offices and courts, Australian law-makers asserted that there was one criminal law in Australia - but persistently gave 
way to the reality that in dealing with Indigenous defendants they were frequently

confronting ways of life and thought that were remote from the Australian mainstream.

\section{How many?}

After the assertion of jurisdiction in the various Australian colonies - itself an index of the transition from wars of occupation to settler hegemony - inter-racial offences were only a fraction of the cases involving Aboriginal offenders brought into the courts for inter-personal violence. Most came to court for killing their kin, wives (more rarely husbands), fellow countrymen with whom they were disputing, or occasionally strangers to their country. Aboriginal people came to court on account of both Aboriginal and white witnessing, they were tried on the evidence of both Aborigines and whites, and they were more often than not saved from the extreme penalty of the law by the exercise of mercy, an outcome of recommendations by white juries and judges.

How common were prosecutions of Aboriginal people for inter-personal violence after the assertion of jurisdiction, and how were they treated? The answer depends on the jurisdiction - but in general over the century after 1850 there was a north-south divide, or more accurately one between the south-east of Australia and the rest of the continent. Although criminal justice statistics are notoriously idiosyncratic across time and place in Australia, it is possible to draw some conclusions from the variety of studies of capital punishment, the mandatory sanction for homicide for most of this period in most of the states. Other evidence may be drawn from studies of inquests, examination of prison records and of course the records of the criminal courts themselves. Detailed studies that take into account the full scope of offences are very rare, even though the richness of Australian criminal justice archives allows the possibility. 
A study of Aborigines and the legal system in South Australia between 1836 and 1862, unique for its close documentation of all the relevant cases, showed results which I suggest are consistent with the impressions gathered from a range of other data. Drawing on court as well newspaper records, Alan Pope counted all prosecutions of Aborigines for murder, manslaughter and assault in the first twenty-five years of the colony - a period that captures frontier and post-frontier conditions, and so is important for showing the gradual transition to inter se offending as the typical characteristic of Aboriginal prosecutions. Pope's data suggests that fifty-six Aborigines were prosecuted for inter se homicide offences of murder or manslaughter in those twenty-five years - in reality in just the fifteen years following the prosecution (later abandoned) of Larry in 1846-7. Many of these (twenty-four defendants) were found not guilty or were discharged when the prosecution was withdrawn. Defendants found guilty of these capital crimes at a time when the mandatory penalty was death always benefited from a reprieve - either commutation to a short term of imprisonment or even a pardon. Such leniency was predictably absent in the sentencing outcomes of those trials of Aborigines charged with killing a European settler in these years - although only a minority was actually found guilty in such trials. There were at least seventy-three so prosecuted, but a majority of these defendants (thirty-eight of them) were found not guilty or had the prosecution discontinued (typically over lack of evidence). Of the thirty-five found guilty of either murder or manslaughter of a European settler, twenty-three Aborigines were executed between 1839 and $1862 .{ }^{6}$ The contrast between inter se and inter-racial cases demands little explanation - beyond reference to the expectation that the ultimate terror of the law would be used as an exemplary lesson to Aborigines who were commonly marshalled to 
observe executions, as well as a demonstration to the settler community that their desire for retribution would be acknowledged. ${ }^{7}$

The substantial scale of inter se prosecution is especially evident in Western Australia over the entire period until the abolition of the death penalty in 1984. Analysis of the capital cases in Western Australia (nearly 600 of them up to the last capital sentence in 1984) shows that Aboriginal defendants made up sixty per cent of the total sentenced to death over this 150 year period, but less than twenty per cent of those convicted were hanged. That is, the great majority of Aborigines convicted of capital offences had their sentences commuted. ${ }^{8}$ But as in South Australia this was in good part the consequence of decisions taken in recognition of the inter se context of the killing. The very large proportion of Aborigines convicted in Western Australia was a consequence both of their relatively numerous population and of the protracted conditions of colonial transition outside the metropolitan area around Perth. After the prosecution of Wewar in 1842, and especially during the governorship of Charles Fitzgerald (1848-1855), it became common to use criminal jurisdiction as one of the means of civilising the Aborigines. ${ }^{9}$ Hence prosecution of inter se killings was common; but the politics of mercy meant few of those convicted suffered the ultimate penalty.

In Queensland, which abolished capital punishment in 1922, Aboriginal defendants were more likely than others to benefit from mercy decisions by the government, but most commonly in inter se cases, which made up the larger part of homicide prosecutions of Aborigines. As in Western Australia we also see strong evidence in Queensland of inter se cases being brought into court at a rate which suggests the determined assertion of jurisdiction as a mode of civilising, even after settler anxieties along the frontiers had 
subsided. The frequency of Aboriginal homicides in the court lists in Queensland suggests that there was no reluctance there to bring Aboriginal defendants in inter se matters before the courts - in some years they made up more than half the defendants in Queensland homicide trials, at a time when Indigenous people made up less than five per cent of the population. ${ }^{10}$

By contrast in south-eastern Australia, in Victoria and New South Wales inter se homicide prosecutions were much less common, although the picture differs between the two states. In the most sophisticated analysis of long-range criminal justice data in Australia, Douglas and Laster showed that only twenty-eight defendants in the 2491 'potentially capital' cases prosecuted in Victoria between 1842 and 1967 (the last year in which a person was executed) were recorded as being Aboriginal. Only one third of these twenty-eight were convicted, one quarter of the total had a sentence of death recorded and only three of those convicted were eventually executed. Douglas and Laster found that 'the offences with which Aboriginal defendants were charged were characteristically offences against whites. ${ }^{11}$ This suggests a remarkable contrast to the greater volume of prosecutions (especially of inter se homicides) in the neighbouring colony of South Australia, let alone in Western Australia and Queensland.

In its colonial history Victoria was more like New South Wales, especially in the absence of large numbers of Indigenous people outside settler control. Although we lack either adequate published criminal justice statistics or a study of the quality of that of Douglas and Laster, examination of New South Wales gaol records suggest that there were also few Aborigines being prosecuted for capital offences in that colony in the later nineteenth century. In the four decades after 1871 the Darlinghurst and Dubbo Gaols which 
received those convicted of capital offences admitted just twenty-two Aboriginal prisoners convicted for a homicide, a small majority of them inter se. ${ }^{12}$ Only three of those convicted of either manslaughter or murder appear to have been executed, all the rest having their sentences commuted. The killing rampage of Jimmy Governor and his brother in the early twentieth century was a cause of sensation - but the intensity of its violence helped amplify its significance in the imagination of long-settled New South Wales. The remaining cases included both inter-racial and inter se cases, with limited reference to the cultural differences which nevertheless led juries and judges to lend support very frequently to the case for mercy. Typically the cases were only briefly reported. But there were exceptions, such as the 1875 prosecution of Jacky Whyman for the murder of his friend Paddy Hadigaddy at Cobargo on the south coast of New South Wales, a trial in which consciousness of imagined and real black and white differences in sensibility and morality preoccupied all in the courtroom. ${ }^{13}$

The pattern described by these contrasting pictures of the volume of prosecutions is one that is explained by the historical intersections of time and space. It is one corresponding to the depth of colonisation in differing parts of Australia - intensive, near genocidal in Tasmania, deep penetration in Victoria and New South Wales, and progressively less complete through central, western and northern Australia, outside the hinterlands of the colonial capitals of Brisbane, Adelaide and Perth. Settler jurisdiction, accomplished in the wake of the violence of the frontier, was focussed largely on crimes of fatal violence. There is one exception - the heavy prosecution of Aborigines for cattle-killing, especially in Western Australia. ${ }^{14}$ 
After the pacification of Indigenous life through subordination or incorporation, the rates of incarceration of Aboriginal people in the most settled parts of Australia were less frequent until much later in the twentieth century. The explanation for this is found in the separation of Aboriginal people from the settler mainstream but also in the management

of their own business by Indigenous people. ${ }^{15}$ Violence resulting in death almost always attracted police attention after the establishment of self-government - but other forms of offending and harm were less visible, less the concern of state agencies and (importantly) may have been handled by preference within Indigenous communities. ${ }^{16}$ Against this brief survey of the incidence of prosecution of inter se violence I turn now to examine the way in which these prosecutions worked.

\section{On trial}

I have outlined above the reasons for concluding that the majority of cases in which Aborigines were prosecuted in Australian criminal courts concerned violence against other Aboriginal people. Once the protracted policy struggle over the admission of Aboriginal testimony had been won (at various points between 1839 and $1876^{17}$ ), the courts in all jurisdictions became used to seeing Aboriginal witnesses as well as defendants in criminal trials. The inter-personal violence that became the subject of criminal prosecution reflected in some jurisdictions the persistence of classical Aboriginal norms and law, but in ways that judges, juries and lawyers found difficult to grasp and interpret. ${ }^{18}$ This was especially the case in all three jurisdictions across northern Australia, where colonisation was least complete. But we cannot assume that in more settled areas violence among Aboriginal people had been assimilated into the forms found in the settler community. I consider here four cases, one from Victoria, two from 
Queensland, a fourth from Western Australia. Despite the varied colonial contexts, Aboriginal people mostly lived in cultural spaces alien to settlers. A consequence was that settler justice meted out to Indigenous inter se murderers, was shaped by essentialised ideas of indigeneity, especially the presumption of a barbarism from which the Aborigines were seen to be escaping only slowly. ${ }^{19}$ Against such a backdrop the law constructed notions of 'custom' or 'tribal habits' that were commonly deployed in explaining Aboriginal violence and deciding on punishment deemed appropriate to it.

Across Australia in late colonial times Aboriginal violent death was commonly interpreted as arising from a way of life remote from settler experience and resistant to intervention. Even those closer to Indigenous families and clans would be reluctant to interfere in private disputes, a reluctance also prevalent in settler communities. But where so much of domestic violence in settler society was in the privacy of homes, in Aboriginal camps it was a public event, observed by others in the camp, and occasionally by non-Indigenous people. Often Aboriginal people assisted the courts in the resolution of cases.

On the Victorian border, at the 1869 inquest into the death of an Echuca woman named Kitty, a leading witness was John Bango, described in the press as an 'intelligent halfcaste', working as a ploughman for a local farmer. His evidence of the violent attack on Kitty led the coroner to ask why he did not interfere in the violence leading to her death. Bango replied, 'It was not my place; I didn’t know he was going to kill her'. He was not the only Aboriginal witness giving evidence to the inquest. Another who deposed for the police was identified simply as Matilda. She knew Kitty well - she was a niece, Kitty being her father's sister. Matilda and Bango both described a row which had developed 
after Davy approached Big Mary at the women’s camp, about fifty yards from the men’s camp, near Deep Creek, Echuca. ${ }^{20}$ Davy, according to Matilda, was wanting to be 'coolie' or 'half-husband' to Big Mary. Whether through jealousy or otherwise Kitty had struck Davy on the head with a stick, then run off towards the men's camp. According to Bango, 'Davy followed her, caught hold of her and "hammered her" in the chest. Matilda tried to part them, but she was unable to do so'. As described by both witnesses Davy had then knocked Kitty down and 'stamped his foot "very hard” upon her chest'. She died about half an hour later, after returning to the women's camp'. As John Bango told the inquest, none of the men had intervened, prompting the coroner's question to him.

Davy had disappeared from the camp, crossing the border into New South Wales. Arrested within the year he was brought to trial in Victoria on a charge of murder. Almost immediately the Crown Prosecutor disowned the charge, telling the jury during the opening address that they might see it as 'manslaughter'. 'Aboriginals', he suggested, 'were not be looked upon, perhaps as similar to Europeans in such cases'. As a man living between two cultures John Bango had already appeared to be on trial in the inquest, being asked to account for his lack of intervention. In the course of the later criminal proceedings he avowed that he himself 'would not hit a woman in return'. Matilda added context to the event - all involved had a 'little beer ${ }^{21}$. In the end, the jury agreed with the Crown Prosecutor. Davy was found guilty of the lesser charge of manslaughter and the judge sentenced him to six months imprisonment, after a hearing which had involved Aboriginal witnesses alone. ${ }^{22}$ The sentence appears light - but there appears no explicit address to the cultural or social context of the killing, in spite of the strong evidence of Indigenous cultural organisation shaping the camp (the gendered division above all), and 
the performance of the violence (the open acknowledgment of jealousy, the use of the stick by Kitty, the seeming restraint of the men observing the attack, treating it as Davy's business). ${ }^{23}$

Aboriginal witnesses in the prosecution of Davy at Echuca showed no reluctance to engage in the process leading to his conviction. Such evidence suggests how the courts had become useful to Aboriginal people themselves as an instrument of justice to redress the damage done by violence resulting in death. In the famous New South Wales case of $R v$ Murrell that had established jurisdiction over inter se killing, the victim's associates had made it clear that they wanted the killers tried in the 'English courts'. ${ }^{24}$ From the early years of the colonial era Aboriginal people took the initiative in bringing to justice the most serious offences in their communities, looking to the settler courts to achieve a resolution. ${ }^{25}$ A notable example is found in the 1910 case of Harry Murphy, found guilty of the manslaughter of his wife Tilly, after he killed her with the blow of a tomahawk at the camp they shared with others on a pastoral property near Taroom in central Queensland. It appeared a stereotypical case of domestic violence.

Aboriginal witnesses to the escalating row between Harry and Tilly described a woman determined to leave a violent man, and return to her relatives. According to the statement of her closest friend in the camp, Tilly had wanted to leave Harry because he was so cruel to their children. In the face of Tilly's rejection of him over the course of a Sunday afternoon and evening, Harry grew more and more belligerent, alternately threatening he would kill or shoot her, and then accepting that she would go, insisting on them shaking hands. In retrospect the insistence was threatening. 
The arrival shortly before the day of the killing, of Tilly's brother Davy, seemed to aggravate Harry's anger. Davy told Harry to leave her alone; and after Tilly refused to go back to Harry's tent she spent the night camped near Davy. Tilly and her women friends had taken Harry's threats seriously, hiding ('planting' they called it) axes and ammunition. Their measures were to no avail - on a Sunday night in March 1910, the enraged Harry found his tomahawk and killed Tilly with a single blow, severing her carotid artery. When Davy woke, he also was attacked by Harry, suffering a serious wound to the head.

Harry, described in the committal papers as a 'half-caste Aboriginal', may have been an outsider but he had re-entered an Aboriginal world. The camp comprised at least three families - all of whom knew it as Jack Hadford's camp, Jack being 'boss'. Jack was away snaring wallabies. Apart from the security offered by being with her other relatives and close associates, Tilly's life in the camp may have benefited from the protection afforded by an older man, Peter Wilson, who also subsisted on 'catching marsupials'. Unlike the more traditional camp at Echuca described earlier, with its men's and women's camps that at Taroom were shared by families who were more nuclear. All of the people lived in tents, some sleeping outside. These were places where everybody shared and knew each other's business but traditional responses to such violence had been modified. Unlike Echuca, here there was intervention and protection for the threatened woman, if ultimately too late. Peter Wilson immediately sought to restrain Harry, first knocking him down and then tying him up when he proved resistant. Peter knew about violence and its results. When he first discovered Tilly he said he knew she had only recently been attacked: 'I saw a cut on left side of neck and blood running away; I saw plenty cut on 
blackfellas, I am getting old now, I say that cut made about five minutes before I saw it'. $^{26}$

It was also Peter who first contacted the police, starting the process resulting in Harry's trial for murder and for unlawful wounding of Davy. The unlawful wounding charge fell through, but Harry was found guilty of manslaughter of Tilly and sentenced like any white defendant - ten years hard labour, a far cry from the Echuca trial's outcome of six months for the same charge. The trial and outcome was in the end free of any of the conventional sources of anxiety to settler courts - the Aboriginal witnesses all spoke English, their stories were consistent, they had acted to bring Harry to justice. Their identities were Indigenous - they described themselves as 'blacks', 'blackfellas', and 'living at the blacks' camp'.It was a place which had its own measure of autonomy and into which they had welcomed Harry and Tilly as people of their own kind, scratching a living from the margins of the settler economy, through the sale of wallaby and possum skins. Harry's conviction and severe punishment might seem to indicate a degree to which Indigenous violence had become indistinguishably subject to the equitable justice of settler courts. But as we will see later, and depending very much on the circumstances of cases, there were other outcomes possible in Queensland inter se murder trials, ones that echoed the developing attention to a notion of Aboriginal 'custom'. That development can be appreciated in the distinctive practice of Western Australian courts through the late nineteenth century in constructing and maintaining an enduring recognition of Indigenous ‘custom' as a factor in sentencing if not an excuse for offending. 
After a hesitant start, Western Australia saw the most intensive use of criminal justice in attempting to deal with Aboriginal inter se violence. ${ }^{27}$ While the better known story is of the large-scale use of imprisonment of Aboriginal offenders from the northern parts of the colony/state from the 1880s to the 1930s, the readiness of local courts and government officials to recognise the Indigenous context of offending was widespread throughout the colony from the mid-nineteenth century. After Governor FitzGerald settled on a path of consistent prosecution of inter se murders after 1848 there were many trials and convictions of Aboriginal defendants. Most of those found guilty had their mandatory death sentences on this capital crime commuted to life imprisonment, serving out their time at Rottnest Island. ${ }^{28}$ The criminal calendars of the Western Australian Supreme Court record frequently the outcome of such trials, with a jury returning a guilty verdict, along with a rider recommending mercy on account of 'tribal custom' having been an element of the offence. Typically such riders were included in the judge's report to the colony's Executive Council which had the final responsibility for ordering an execution or commutation of the sentence. ${ }^{29}$ Hence while nearly two-thirds of capital convictions in Western Australia were of Aboriginal defendants, only one in five of those eventually executed were Aboriginal.

Such case outcomes were by no means restricted to murder trials arising in Indigenous communities of the northern parts of the colony, among people living still in their own country and only marginally linked to the settler economy and society. Neither were such outcomes uncontroversial. Just as the Swan River governing elite (especially Governors Stirling and Hutt and Advocate-General George Fletcher Moore) had debated at length in the 1830 s whether they should interfere in 'native disputes between themselves, ${ }^{30}$ so 
settler opinion a half-century later was unsettled by mercy decisions that singled out Aboriginal defendants from others.

In 1883 the West Australian newspaper editorialised at length on the politics of mercy, wondering whether justice was really served by its administration in the case of an Aboriginal man (Ben Ben) recently convicted of the murder of Lizzie, a young Aboriginal girl described as a half-caste, at a farm south-east of Perth. The case had been prosecuted in the same sessions as that of a white man, Henry Haynes, convicted for the murder of his wife Ann. Haynes was a 'bond' man - a ticket-of-leave convict who had been transported for life in 1859 on a murder conviction. Ben Ben was an Indigenous man, perhaps of the country around the Williams River, but his particular social context was little explored in the police investigation or the trial. Rather, as the West Australian mooted, the jury and judicial evaluation of the context of his action in killing Lizzie seemed to arise from a readiness to accept any reference to Aboriginal custom as a mitigating factor in a crime. So 'while Haynes is to suffer the extreme penalty of the law, Benben, the murderer of the unfortunate girl Lizzie is to have his sentence commuted to penal servitude for life’.

For the West Australian such an outcome was a moral hazard to victims of crime. 'There can be no doubt', the editorial continued, 'that numbers of unfortunate aboriginals meet with violent deaths owing to the leniency with which horrible barbarities on the part of the natives are treated whenever there is the slightest ground for attributing them to “tribal custom”.' The problem lay with ‘town juries’ which were inclined to lump all Aborigines together' they 'imagine that, in the case of the crimes of those who have been brought up under the influences of civilization, tribal custom is as valid an excuse as it 
might be where the perpetrator is really imbued with the spirit of aboriginal law and tradition'. ${ }^{31}$ Leniency of the kind exhibited in the case of Ben Ben was no mercy but an encouragement of further atrocities.

In truth the case of Ben Ben’s homicide of Lizzie was one whose customary contexts were obscure but by no means absent. Indeed the only motivation for Ben Ben's action that emerged from any of the inquiries conducted by police was found in the consistent story presented by three witnesses that he had killed Lizzie because his own mother had died some weeks before. That was what he himself told the arresting police sergeant, who carefully recorded that he had warned Ben Ben not to say anything to him; it was also given in evidence by Ben Ben’s partner Minnie, whose status as ‘his woman’ was no barrier to her being a compellable witness in colonial courts. ${ }^{32}$ An associate of Ben Ben, Woodar, also testified that his friend had told him that he killed the girl Lizzie because his mother was dead. In Ben Ben’s own statement reported by the arresting police constable he claimed that another Aboriginal man had said to him that 'Lizzie's no relation of yours and your mother died and you ought to kill her ... if you don't kill her you are a coward'. Ben Ben said he had used no spear; he had strangled her. Medical evidence suggested the same, although the body was not inspected before its condition had deteriorated to a skeletal state. ${ }^{33}$

The murder had taken place at a sheep farm at Minigen near Williams, a small town on the road from Albany to Perth. Lizzie was described by Johanna Barron, wife of sheep farmer Edward Barron, as 'a half-caste girl in my employ'. She had been with the Barrons about five or six years, could read and write and was employed in domestic duties. On the day she was killed, Lizzie was minding sheep. Ben Ben alone mentioned 
that accompanying her was the Barron's daughter. Nobody added any more detail to the events that Ben Ben recounted in his statement to police: 'My woman and me left Mary Ann Barron \& Lizzie with the sheep, I went away and watched them and when Mary Ann Barron went away I went back \& saw Lizzie walking about with the sheep. I caught her and choked her with my hand. I never used no spear’. Ben Ben was known to the Barrons, Johanna said, for some years. He and Minnie were not the only Aboriginal people in the area for Johanna's memory was that on the day Lizzie was missing 'all the natives cleared from Minnigen that morning, the prisoner and his woman among them'. It was more than a month before the body was discovered. In other evidence Woodar, also a shepherd for a local farmer, indicated that Ben Ben and Minnie had stayed with him a few days in the intervening time and that Ben Ben had told him he had killed Lizzie. It was Woodar who sent information to the police reporting Lizzie’s death. Ben Ben did nothing to deny his guilt - as he reportedly told Constable Walker, 'I will tell the Magistrate when I go to Court all about it. I have got it all on my tongue. You don't want Woodar for a witness at all' ${ }^{34}$

No evidence was led as to the customs or norms which might have justified or explained Ben Ben's actions. All was left to imputation. In this sense the West Australian editorial pointed to a reality of colonial court practice when it came to dealing with offences between Aborigines. Courts were all too ready to accept references to 'custom' or 'barbaric practices' as sufficient in itself to explain violent events that were beyond the understanding of prosecutors, judges or juries. In prosecuting the case the AttorneyGeneral put it to the jury that the murder of Lizzie was 'one of those tribal outrages in which a life was sacrificed in deference to some custom prevailing among the aboriginal 
inhabitants of the colony - that where one of their relatives died, it was advisable, or necessary or expedient that they should take the life of someone else'. This 'barbarous custom' could form no legal defence 'since all classes of the community were subject to the British law, which makes no distinction between black or white'. The defence counsel was no more informative on context or 'custom', but asked the jury to accompany their inevitable verdict 'with a recommendation to mercy on the ground that the outrage was the outcome of a tribal custom'. The jury complied. ${ }^{35}$ After the passing of the sentence, the commutation was little more than a formality. Ben Ben was sent to Rottnest - his own death was reported from there within three years of his confinement. ${ }^{36}$

Ben Ben’s case highlights the issues confronting courts during a time of transition for Indigenous populations now living in daily contact with settler society but maintaining their own social world, one which remained for the most part impervious to their settler neighbours. The endorsement of 'custom' as a mitigating factor in sentence outcomes was seemingly less likely in cases where the Aboriginal defendant was well known to local settlers and living on the margins or even more centrally in the local economy - as Ben Ben appears. Yet unlike those earlier cases we have examined, of Davy at Echuca or Harry Murphy at Taroom, conditions in the jurisdiction where Ben Ben was tried were highly conducive to 'custom' being invoked, even where it was little tested and where there were those sceptical of its application, such as the writer of that West Australian editorial. Few such doubts appear in northern Australian trials where gradually customary law was becoming a standard explanation of the behaviour of Aboriginal defendants and would become the core of a policy debate about the need for Native Courts in the twentieth century. ${ }^{37}$ While this is not the place to canvass the issues then developed, we 
may consider a final example of Aboriginal defendants in the late colonial period when ‘custom' was positively invoked as explanation and mitigation, with none of the doubts emerging in that 1883 case.

In the Queensland criminal court sitting at Townsville in 1902, two Aborigines identified as Willie and Dick were tried for the murder of Frank another Aboriginal man. Frank's body had been discovered by a fourteen year old boy in a waterhole near Ingham, about a mile from 'the blacks' camp'. Signs of mutilation initially suggested some similarity to a murder in the same district the previous year of a Pacific Islander; the first newspaper reports reported Frank as a 'Kanaka'. Nothing in the trial notes explained how the police came to interview Willie and Dick. Although other Aboriginal witnesses were called to give evidence, the case rested entirely on the prisoners' own statements. In spite of defence counsel asking the jury whether they would find two white men guilty of wilful murder on such evidence, the jury found Dick not guilty but Willie guilty, attaching a recommendation to mercy 'on account of the customs of the Aboriginals'. Recommending the prisoner to the mercy of the Crown, Judge Chubb of the Supreme Court did not elaborate on precisely what customs were involved, leaving the inference to be drawn from his brief statement of the facts of the case. These had involved evidence of the two men (along with a third whose absence from the trial was unexplained) having sliced flesh from the arms which they had later cooked and eaten. In court one police officer with fifteen years experience in the North alluded to a putative customary basis for the killing, in the fact that Frank was said to be a Townsville black and so a stranger to the area. It was, he told the court, 'a common thing in N. Queensland for blacks to kill strange blacks who come into their district. They consider they have a right to do this. I 
think the reason is that the stranger intrudes on their rights and tends to take away their work'. But in his statement tendered as an exhibit in court but not made the subject of cross-examination or further comment, Dick offered a more substantive explanation of motive when he claimed that Willie had accused Frank of killing his (Willie’s) brother in Cairns some time before. Counsel, jury, judge and reporters found no reason in such suggestions to enquire into the possible wider field of meaning of such killings. Instead 'custom' became a generic explanation for the violent acts of Aboriginal people whose lives and mentality were opaque to those from the settler culture. Like most Aboriginal defendants sentenced to death after conviction for murder of another Aborigine, Willie had his sentence commuted to penal servitude for life, in his case ending in a discharge after nine years in prison. ${ }^{38}$

\section{Conclusion}

The contemporary legacy of contention over the nature and role of so-called customary law can only be understood adequately through an appreciation of the historical construction of the very idea of 'custom' as it was deployed in courts and in clemency decisions. When criminal law’s authority over Indigenous people became a test of Crown sovereignty in Australia the outcome was something that inevitably entailed colonialism's logic and invoked the cultural assumptions of those who bore responsibility for bringing killers before courts. In the little studied archives of Australia's criminal courts over the century between the 'perfection of sovereignty' ${ }^{39}$ and the emerging struggles for Aboriginal citizenship rights we also find much more - justice administered in conditions that unsettled law's comfort in its own procedures and its capacity to understand the actions of those whose lives it judged. We have seen in this brief scan of 
cases involving Aboriginal defendants who had killed other Aboriginal men and women and children, the way in which justice alternately ignored the cultural and social contexts and meanings of Indigenous behaviour or else folded the fleeting apprehension of these contexts into a general assumption about the continuing influence of 'custom' on Aboriginal people. In the process law was wielded less heavily than might be expected, in ways which we conclude might be both benign to defendants and a hazard to the potential victims of violence.

The encounters of Australian criminal law with Indigenous people did not flow only one way. Law was changed by its encounter, having to adjust to the realities it dealt with in the continuing colonial problem of how to govern an Indigenous population. Over the longer term the ways in which criminal law was changed included evidence (the admission of Aboriginal testimony), juries (the Northern Territory amendments of the 1920s restricting the use of juries in criminal law to capital offences), the establishment of special jurisdictions (Native Courts in Western Australia), the recognition of customary wives as entitled to exclusion from compulsion to testify against their partners (legislated in the Northern Territory and Western Australia in the 1930s), and especially in the frequency of sentence mitigation, the most enduring outcome of the encounter with 'custom', and one that survived (controversially) into the twenty-first century. ${ }^{40}$ The traces of the emergence of the idea of 'custom' as a mitigating factor in sentencing are readily discovered in the nineteenth century criminal calendars - but it is only when we delve into the circumstances of such trials that we come to see the ways in which 'custom' was both elastic in its meaning and an avoidance of detailed inquiry into the context of offending. In this way the encounter of Australian criminal law with the results 
of Aboriginal violence provides an important opportunity to understand the way in which two cultures were contesting over their preferred responses to violence.

\footnotetext{
${ }^{1}$ Katherine Biber, “Besieged at home: Jimmy Governor’s rampage,” Public Space: The Journal of Law and Social Justice 2 (2008), http://epress.lib.uts.edu.au/ojs/index.php/publicspace/article/view/785 (acc 5 Aug 2010); Maurie Garland, Jimmy Governor: Blood on the Tracks (Melbourne: Brolga Publishing, 2009); Ted Egan, Justice all their own: The Caledon Bay and Woodah Island Killings 1932-1933 (Melbourne: Melbourne University Press, 1996); Peter Read, "Murder, revenge and reconciliation on the North Eastern frontier,” History Australia 4, no. 1
} (2007): 09.1-09.15; K. S Inglis, The Stuart Case (Melbourne: Black Inc., 2002).

${ }^{2}$ Most recently Tracey Banivanua-Mar, Violence and Colonial Dialogue: The Australian-Pacific Indentured Labor (Honolulu: University of Hawai ‘ i Press, 2007); Martin J Wiener, An Empire on Trial: Race, Murder, and Justice Under British Rule, 1870-1935 (Cambridge: Cambridge University Press, 2009); Amanda Nettelbeck and Robert Foster, In the name of the law : William Willshire and the policing of the Australian frontier (Kent Town, S. Aust.: Wakefield Press, 2007); Tony Roberts, Frontier justice : a history of the Gulf country to 1900 (St Lucia, Qld.: University of Queensland Press, 2005).

${ }^{3}$ Lucy Snowball and Don Weatherburn, “Theories of Indigenous Violence: A Preliminary Empirical Assessment,” Australian and New Zealand Journal of Criminology, The 41, no. 2 (August 2008): 216-235. 
${ }^{4}$ Richard Broome, Aboriginal Australians: a history since 1788 (Sydney: Allen \& Unwin, 2010), 74-76; Richard Broome, Aboriginal Victorians: A History Since 1800 (Sydney: Allen \& Unwin, 2005), 84-87.

${ }^{5}$ Bruce Kercher, “R v Ballard, R v Murrell and R v Bonjon - [1998] AILR 27; (1998) 3 AILR 410,” n.d., http://www.austlii.edu.au/au/journals/AILR/1998/27.html\#fnB6; Lisa Ford, Settler Sovereignty: Jurisdiction and Indigenous People in America and Australia 1788-1836 (Cambridge, Mass: Harvard University Press, 2010); Ann Hunter, “The boundaries of colonial criminal law in relation to inter-Aboriginal conflict ('Inter Se Offences') in Western Australian in the 1830s-1840s," Australian Journal of Legal History 8, no. 2 (2004): 215-236; D Ward, "Constructing British authority in Australasia: Charles Cooper and the legal status of Aborigines in the south Australian Supreme Court, c. 1840-60,” Journal of Imperial and Commonwealth History 34, no. 4 (2006): 483-504; R H W Reece, "Laws of the white people: the frontier of authority in Perth and early Western Australia," in International Law and Aboriginal Human Rights, ed. Barbara Hocking (Sydney: Law Book Company, 1988); R. Reece, Aborigines and Colonists: Aborigines and Colonial Society in New South Wales (Sydney: Sydney University Press, 1974.).

${ }^{6}$ Alan Pope, "Aborigines and the criminal law in South Australia: the first twenty five years” (PhD, Deakin, 1998).

${ }^{7}$ For the exemplary use of public hanging of Aboriginal defendants see John McGuire, “Judicial violence and the 'civilizing process': Race and the transition from public to private executions in Colonial Australia,” Australian Historical Studies 29, no. 111 (1998): 186-209; Amanda Nettelbeck and Robert Foster, 'Colonial Judiciaries, 
Aboriginal Protection and South Australia’s Policy of Punishing “with Exemplary Severity”’, Australian Historical Studies, 41:3 (2010): 319-336.

${ }^{8}$ This analysis is based on the case data documented in Brian Purdue, Legal Executions in Western Australia (Victoria Park, W.A: Foundation Press, 1993): note that this period (1837-1984) included years when capital punishment was an available penalty for nonhomicide offences including rape. Although Purdue’s study is poorly referenced it was based on a review of the criminal calendars in the Western Australia State Record Office - my sampling of these suggests that Purdue’s study is generally a reliable account.

${ }^{9}$ See Paul Hasluck, Black Australians (Melbourne: MUP, 1942), 129-130 on Fitzgerald’s determination to pursue prosecution of Aboriginal offenders.

${ }^{10}$ Mark Finnane and Jonathan Richards, “Aboriginal violence and state response: histories, policies, legacies in Queensland 1860-1940,” ANZ Journal of Criminology 43, no. 2 (2010): 238-262.

${ }^{11}$ Roger Douglas and Kathy Laster, “'A matter of life and death: the Victorian Executive and the decision to execute 1842/ 1967',” Australian and New Zealand Journal of Criminology 24, no. 2 (July 1991): 153.

12 These figures derive from the author's accessing the Darlinghurst and Dubbo Gaol photo books (State Records New South Wales, reels 5096-5117), complemented by press reports of the associated trials.

13 Jacky Whyman trial, Sydney Morning Herald 11 May 1875, p 7; commutation Sydney Morning Herald, 9 June 1875 p. 5. Ultimately, in spite of the death sentence being commuted to life imprisonment, Whyman served only 8 years, being discharged in May 
1883 - Darlinghurst Gaol Photographic Description Book 3/13401, fol 95, (reel 5098), State Records NSW.

${ }^{14}$ Andrew Gill, “Aborigines, Settlers and Police in the Kimberleys, 1887-1905,” Studies in Western Australian History 1 (1977); Chris Owen, “'The police appear to be a useless lot up there': law and order in the East Kimberley 1884-1905,” Aboriginal History 27, no. 2003 (2003): 105-130; Howard Pedersen and Banjo Woorunmurra, Jandamarra and the Bunuba resistance (Perth, W. A.: Magabala books, 2000).

${ }^{15}$ See especially Heather Goodall, Rivers and Resilience: Aboriginal People on Sydney's Georges River (Sydney: University of New South Wales Press, 2009); Heather Goodall, Invasion to embassy : land in Aboriginal politics in New South Wales, 1770-1972 (Sydney: Allen \& Unwin in association with Black Books, 1996); Broome, Aboriginal Victorians; Jimmie Barker, The Two Worlds of Jimmie Barker: The Life of an Australian Aboriginal, ed. Janet Mathews, Australian Aboriginal studies (Canberra: Australian Institute of Aboriginal Studies, 1977); Ruby Langford, Don't take your love to town (Melbourne: Penguin, 1988).

${ }^{16}$ Reporting fieldwork conducted at Yirrkala in the 1970s , anthropologist Nancy Williams described the tendency of people to distinguish between 'big troubles' (managed by Australian law) and 'little troubles’ (managed by themselves): Nancy Williams, Two Laws: managing disputes in a contemporary Aboriginal community (Canberra: AIAS, 1987), 129-38.

${ }^{17}$ Ann Hunter, “The origin and debate surrounding the development of Aboriginal Evidence Acts in Western Australia in the early 1840s,” Law Review 9 (2007): 115-145; Nancy E Wright, “The problem of Aboriginal evidence in early colonial New South 
Wales," in Law, history, colonialism: the reach of empire, ed. Diane Elizabeth Kirkby and Catharine Coleborne (Manchester; New York New York: Manchester University Press ; Distributed in the USA by Palgrave, 2001), xii, 307 p.

${ }^{18}$ I have adopted the term 'classical' in the sense used by Sutton to denote Aboriginal law at the point of contact: Peter Sutton, Native Title in Australia: An Ethnographic Perspective (Cambridge: Cambridge University Press, 2003).

${ }^{19}$ Bruce A Buchan, The empire of political thought: indigenous Australians and the language of colonial government (London: Pickering \& Chatto, 2008); Ann McGrath, “'Modern Stone Age Slavery': images of Aboriginal labour and sexuality,” Labour History, no. 69 (November 1995): 30-51.

${ }^{20}$ For conditions at Echuca around this time, including the persistence of camp life: Nancy Cato, Mister Maloga: Daniel Matthews and His Mission, Murray River, 18641902 (Brisbane, Qld: University of Queensland Press, 1976).

${ }^{21}$ Daniel Matthews, founder of the Maloga Mission, described in his diaries the damaging effects of drinking among the Aboriginal communities around Echuca: see Ibid., xx. 31-32. For the violence associated with alcohol abuse at this time see Broome, Aboriginal Victorians, 157-159.

${ }^{22}$ Case of Davy (Sandhurst Circuit Court), Argus, 16 Mar 1869 (inquest); Argus, 12 Feb 1870, p 6 (trial); Riverine Herald, 16 Feb 1873, p 3 (trial).

${ }^{23}$ On modes and discourses of Aboriginal fighting see especially Victoria Katherine Burbank, Fighting Women: Anger and Aggression in Aboriginal Australia (Berkeley: University of California Press, 1994); Eric Venbrux, A Death in the Tiwi Islands (Melbourne: Cambridge University Press, 1995); Marcia Langton, "Medicine Square,” in 
Being Black, ed. Ian Keen (Canberra: Aboriginal Studies Press, 1988); Basil Sansom, The Camp at Wallaby Cross: Aboriginal Fringe-dwellers in Darwin (Canberra: Australian Institute of Aboriginal Studies, 1980).

${ }^{24}$ In events leading up to the trial of Jack Congo Murrell in 1836, the missionary Lancelot Threlkeld, wrote to the Attorney-General, informing him that he had been advised by an Aboriginal man, Bowen Bungaree, that 'both he and his tribe wish the two prisoners, George Bummery and Jack Congo Murrill [sic] to be tried by the English for the murder of his Brother in Law in Windsor’: Original Documents on Aborigines and Law 1797-1840 (Document 41)`Mr Threlkeld to Atty Genl - blacks request that Jack Congo Murrall should be tried by English: February 1836’ $<$ http://www.law.mq.edu.au/scnsw/Correspondence/41.htm> [accessed 15 February 2010].

${ }^{25}$ Argus, 10 Oct 1860 p 5, 11 Oct 1860, p. 5.

${ }^{26}$ R v Harry Murphy, Toowoomba 29 Mar 1910 CCT4/N50, QSA.

${ }^{27}$ On the early colonial debates regarding prosecution of inter se offences see especially R H W Reece, "Laws of the white people: the frontier of authority in Perth and early Western Australia”; Hunter, “The boundaries of colonial criminal law in relation to interAboriginal conflict ('Inter Se Offences') in Western Australian in the 1830s-1840s”; Paul Hasluck, Black Australians (Melbourne: MUP, 1942).

${ }^{28}$ For a comprehensive review of the history of Rottnest as a prison and of its prisoners, see Neville Green and Susan Moon, Dictionary of Western Australians. Volume X. Far from home, Aboriginal prisoners of Rottnest Island 1838-1931 (Perth: University of Western Australia Press, 1997). 
${ }^{29}$ Purdue, Legal Executions in Western Australia; Simon Adams, The Unforgiving Rope: Murder and Hanging on Australia's Western Frontier (Perth: UWA Publishing, 2009). The way in which mercy decisions were processed and managed in the nineteenth and early twentieth centuries is best examined in Carolyn Strange, ed., Qualities of mercy : justice, punishment, and discretion (Vancouver, B.C.: UBC Press, 1996); C. Strange, "Masculinities, intimate femicide and the death penalty in Australia, 1890-1920," British Journal of Criminology 43, no. 2 (2003): 310-339. For the

${ }^{30}$ See above n. 28; Moore's diaries and letters give an intimate account of these debates: George Fletcher Moore, The Millendon Memoirs: George Fletcher Moore's Western Australian Diaries and Letters, 1830-1841, ed. J. M. R Cameron (Carlisle, W.A: Hesperian Press, 2006).

${ }^{31}$ West Australian, 22 January 1883, p 3.

${ }^{32}$ The compellability of Aboriginal wives to give evidence in court was considered in the NSW Supreme Court in 1883 and decided in favour of compulsion, disregarding the customary status of Aboriginal marriage - on $R v$ Cobby see Henry Reynolds, Aboriginal sovereignty: reflections on race, state and nation (St Leonards, N.S.W.: Allen \& Unwin, 1996), 74. On the later (1930s) policy debates on the issue see Tony Austin, Never trust $a$ government man : Northern Territory Aboriginal policy 1911-1939 (Darwin: NTU Press, 1997), 242-45; Alison Holland, “Compelling Evidence: marriage, colonialism and the question of Indigenous rights,” Women's History Review 18, no. 1 (2009): 121.

${ }^{33}$ In the informal mode possible in remote courts the medical evidence was provided by the magistrate who took the depositions, John Crampern Rosselloty, who was also Medical Officer in the Williams District. 
${ }^{34}$ All quotes from depositions on the indictment file, $\mathrm{R} v$ Ben Ben alias Brandy, Cons 3473, Item 121, WA SRO.

${ }^{35}$ West Australian, 10 Jan 1884, p. 3.

${ }^{36}$ Green and Moon, Dictionary of Western Australians. Volume X. Far from home, Aboriginal prisoners of Rottnest Island 1838-1931, 110-111.

${ }^{37}$ See Austin, Never trust a government ma : Northern Territory Aboriginal policy 19111939; Kate Auty, Black glass : Western Australian courts of native affairs 1936-54 (Fremantle, W.A.: Fremantle Arts Centre Press, 2005); A P Elkin, “Aboriginal Evidence and Justice in North Australia,” Oceania, xvii, no. 3 (1947): 173-210; Mark Finnane, “The tides of customary law,” ANZLH E-Journal (http://www.anzlhsejournal.auckland.ac.nz/pdfs_2006/Keynote_1_Finnane.pdf) (2007). ${ }^{38}$ Papers re The King v Willie, A/19958, QSA; Brisbane Courier, 3 July 1902 p 4; Willie was discharged from gaol in 1911, Queensland Police Gazette, 1911, 48:23. ${ }^{39}$ Ford, Settler Sovereignty.

${ }^{40}$ Mark Finnane, “The limits of jurisdiction: law, governance and Indigenous peoples in colonised Australia," in Law and Politics in British Colonial Thought: Transpositions of Empire, ed. Shaunnagh Dorsett and Ian Hunter (London: Palgrave, 2010). 